BANGLADESH JOURNAL OF SCIENTIFIC AND INDUSTRIAL RESEARCH

E-mail: bjsir07gmail.com

BCSIR

\title{
Impact of the Effluents of Textile Dyeing Industries on the Surface Water Quality inside D.N.D Embankment, Narayanganj
}

\author{
Mahfuza. S. Sultana, ${ }^{a *}$ M. Shahidul Islam, ${ }^{b}$ Ratnajit Saha ${ }^{a}$ and Al- Mansur M. A.b \\ ${ }^{a}$ Department of Environmental Sciences, Jahangirnagar University, Savar, Dhaka. \\ ${ }^{b}$ Analytical Research Division, Bangladesh Council of Scientific and Industrial Research \\ (BCSIR) Laboratories, Dhaka, Bangladesh.
}

\begin{abstract}
The study was carried out in order to assess the impact of the various pollutants of textile dyeing effluents on the surface water quality of the industrial area inside Dhaka-Narayanganj-Demra (D.N.D) embankment, Narayanganj. Physicochemical parameters such as TSS, TDS, DO, pH, EC, Turbidity, BOD, COD, anionic parameters such as $\mathrm{F}^{-}, \mathrm{Cl}^{-}, \mathrm{NO}_{2}{ }^{-}, \mathrm{NO}_{3}{ }^{-}, \mathrm{SO}_{4}{ }^{-}$and $\mathrm{PO}_{4}{ }^{3-}$ and heavy metals such as $\mathrm{Pb}, \mathrm{Zn}, \mathrm{Cd}$ and $\mathrm{Cu}$ of the samples were investigated by using various techniques. The results showed that, textile dyeing industries inside D.N.D embankment area discharges effluents composed of various physicochemical and anionic pollutants at considerably higher level compared to pollution limit. Further, the surface water of the D.N.D channel, ponds and lakes around the studied textile dyeing industries also contain various physicochemical and anionic pollutants at intolerable limit. A significant correlation was also observed among some important water parameters of the effluents and surface water. The above findings point out that the surface water around the studied textile dyeing industries is highly polluted by the industrial activities of the D.N.D. embankment area and not good for human consumption.
\end{abstract}

Key words: Industrial effluents, D.N.D embankment, Surface water quality, Environmental impact.

\section{Introduction}

Industrial pollution is one of the vital problem presently facing Bangladesh and all over the world. The careless disposal of industrial effluents and other wastes may contribute greatly to the poor quality of the water (Chindah et al, 2004). Textile industries are major sources of these effluents (Ghoreishi et al, 2003) due to the nature of their operations which requires high volume of water that eventually results in high waste water generation. They are one of the largest of water users and polluters (Nemerow, 1978).The extent of color and metals contamination of the water environment has

* Corresponding author, E- mail: mssultana@bdonline.com 
raised much concern because of potential hazards associated with the entry of these substances into the food chain of humans and animals.

Textile is the most important sector of Bangladesh's economy. Textile industry uses a large quantity of water in its production processes and highly polluted and toxic waste waters are discharged into sewers and drains without any kind of treatment (Chindah et al, 2004).The D.N.D Embankment, Narayanganj is one of the prominent embankments of Bangladesh. There are a large numbers of textile dyeing industries functioning surrounding D.N.D embankment. More than $80 \%$ industries have no industrial large treatment plant for effluent discharge. Less than $2 \%$ are composite units (knitting, dyeing, finishing) which have proper treatment plants. Industrial wastes comprise different types of solid waste, liquid wastes, and gaseous waste. Their characteristics are different from the municipal and the commercial wastes (Park, 1980; Rahman et al, 2002).

The textile dyeing industries of Narayanganj generate a large amount of effluents, sewage sludge and solid waste materials everyday which are being directly discharged into the surrounding channel, agricultural fields, irrigation channels, surface water and finally enter in to the Shitalakshya River. Textile and dyeing industrial effluents offer the alteration of physical, chemical, and biological properties of aquatic environment by counting change in temperature, odor, noise, turbidity, and to the original properties that is harmful to public health, livestock, wildlife, fish, and other biodiversity (Haque et al., 2002). The presence of dyes in surface and subsurface water makes them not only aesthetically objectionable but causes many water borne diseases, viz. nausea, hemorrhage, ulceration of skin and mucous membrane, dermatitis, perforation of nasal septum and severe irritation of respiratory tract. Contamination to this aquatic system brings serious threat to the overall epidemic and socio-economic pattern inside D.N.D embankment. Industrial effluents impart a minor fraction of chemical load to the environment; its integrity renders the environmental quality fairly deplorable. For this, a large number of villages inside D.N.D Embankment are now being threatened by the environmental degradation. People who live surrounding area of D.N.D. Embankment utilizing surface water for their house hold washing, bathing, irrigation, fish culture and other necessary works. Further no systemic data was found about the water quality of the D.N.D. area. So, proper analysis is needed to assess the pollution level also for the protection of environment and natural resources. Such information is important for the authorities to take proper action in preventing pollution of the area inside D.N.D. Embankment for the good health of the population. Therefore in the present study we tried to determine the extent of pollution level of various physicochemical, anionic 
parameters and heavy metals in order to characterize the effluents of the textile dyeing industries inside D.N.D. embankment industrial area, Narayanganj. Further the impact of the pollutants of the effluents on the surface water quality was also determined by measuring the pollution level of the various parameters of the surface water of the D.N.D main channel, ponds and lakes of the studied industrial area.

\section{Materials and Methods}

\section{Study Area}

Dhaka-Narayanganj-Demra (D.N.D) Embankment located mainly at Narayanganj District. The study area lies between $23^{\mathrm{O}} 38^{\prime}$ and $23^{\circ} 44^{\prime}$ North latitude and $90^{\circ} 26^{\prime}$ and $90^{\circ} 32^{\prime}$ East longitude. The Total boundary of the D.N.D embankment is app. $30528.44 \mathrm{~m}$. There is app. 4450 small and big houses, 1450 school, colleges, research institutions and 2971 commercial activity places are situated inside D.N.D. Embankment. Further approximately 242 industries such as textile dyeing industry, pharmaceuticals industry, food manufacturing industry, cottage industry, plastic and rubber product, Paper and paper product, leather goods and products are situated inside D.N.D. embankment. Of them app. 80\% industries are textiles dyeing industries, which discharge huge amount of effluents, sewage sludge and solid waste materials directly into the surrounding water body of this area.

\section{Sample collection}

In this study, the sampling sites are located inside D.N.D. embankment industrial installation. Twenty one (21) samples were collected from the study area. Among them nine (9) effluent samples were collected from the discharge points and combined drain of the various textile dyeing industries (Figure-1a) and twelve (12) surface water samples were collected from the D.N.D main channel, ponds and lakes of different locations around the various textile dyeing industries inside D.N.D. Embankment (Fig. 1b). Collection and analysis of the samples were performed in May-June, 2007 by proper sampling procedure. The locations of the sampling sites and sources with ID numbers are shown in Table Ia and Ib.

\section{Sample analysis}

The physicochemical parameters, anion concentrations and heavy metal concentrations of effluents samples and surface water samples were analyzed by different standard methods in Analytical Research Division, BCSIR Laboratories, Dhaka \& Environmental Research Laboratory, Department of Environmental Sciences Jahangirnagar University. Physicochemical parameters such as Color Odor, Temperature, Total suspended 


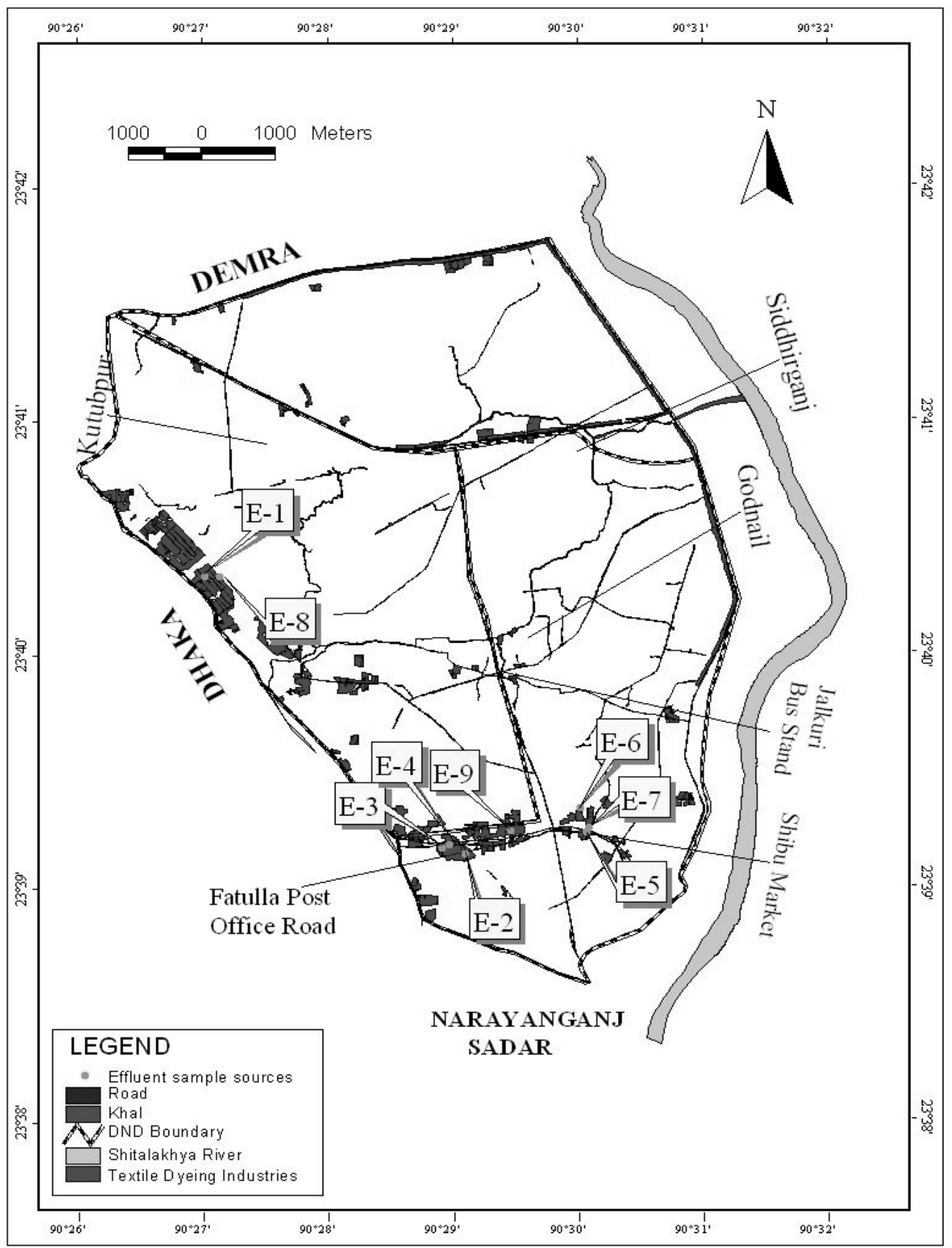

Fig. 1a. The locations of the effluent samples of the various textile dyeing industries inside D.N.D embankment area. 


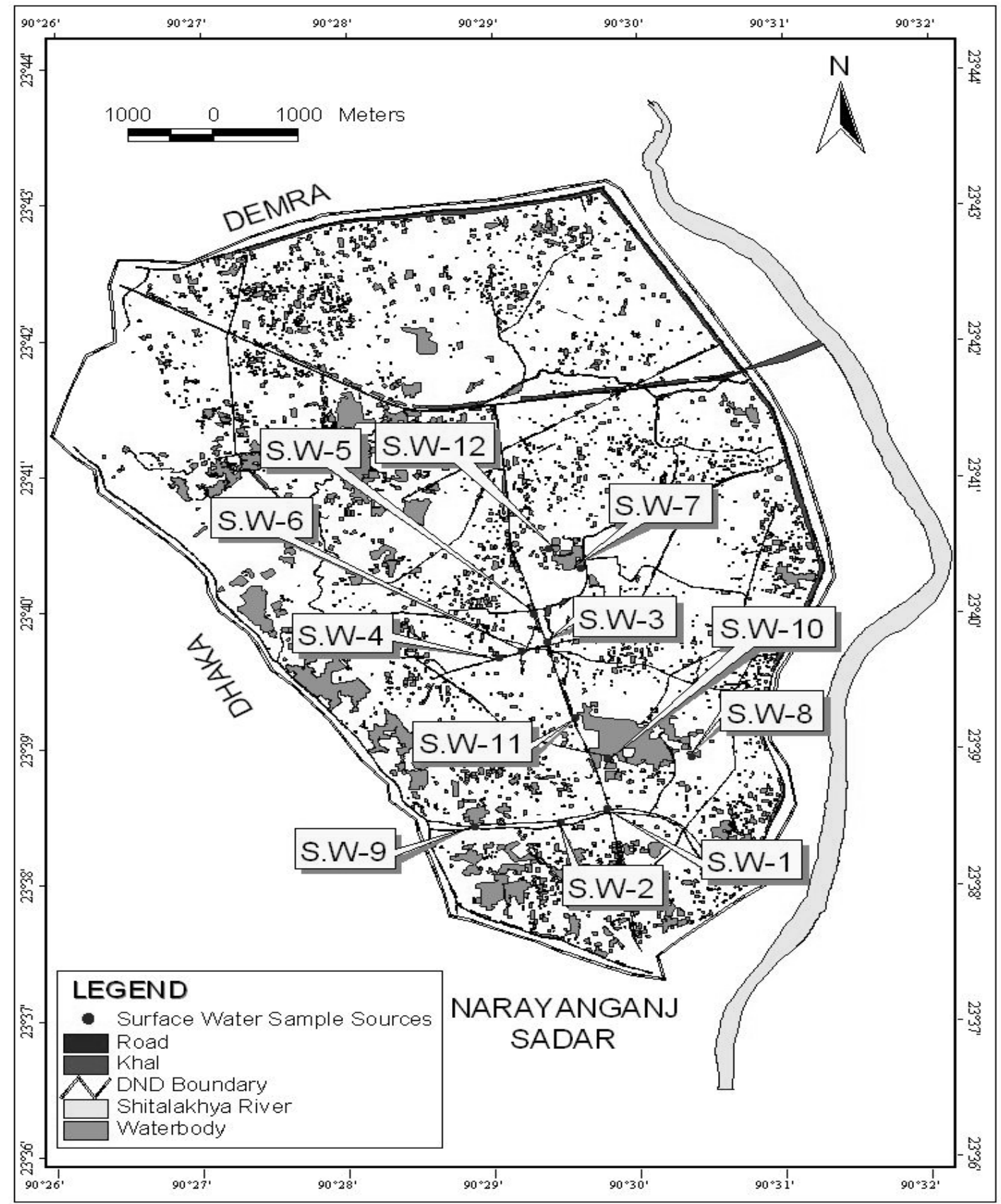

Fig. 1b. The locations of the surface water samples collected from the D.N.D embankment area. 
Table Ia. Locations and sources of the sampling sites of the effluent samples with ID numbers.

\begin{tabular}{|c|c|c|c|}
\hline SL. No. & Sampling sites & Sources & Sample ID \\
\hline 1 & $\begin{array}{c}\text { Evana Textile \& Dyeing Mills Ltd. of Shampur } \\
\text { Industrial Zone. }\end{array}$ & $\begin{array}{l}\text { Connected drain of } \\
\text { industries }\end{array}$ & E-1 \\
\hline 2 & $\begin{array}{c}\text { Rony Dyeing Ltd. of Fatulla Post Offic Road } \\
\text { Industrial Zone }\end{array}$ & $\begin{array}{l}\text { Connected drain of } \\
\text { industries }\end{array}$ & $\mathrm{E}-2$ \\
\hline 3 & $\begin{array}{c}\text { Fatullah Dyeing and Calendaring Mills Ltd. Of } \\
\text { Fatulla Post Office Road Industrial Zone }\end{array}$ & $\begin{array}{l}\text { Discharge point of } \\
\text { industries }\end{array}$ & E-3 \\
\hline 4 & Fatullah Dyeing and Calendaring Mills Ltd. & $\begin{array}{l}\text { Discharge point of } \\
\text { industries }\end{array}$ & E-4 \\
\hline 5 & Shibu Fashion Mills Ltd. Of Shastarpur & $\begin{array}{l}\text { Discharge point of } \\
\text { industries }\end{array}$ & E-5 \\
\hline 6 & $\begin{array}{l}\text { Rupashi Group (Rupashi Textile and Dyeing } \\
\text { Mills Ltd.) of Lamapara, Fatullah }\end{array}$ & Connected drain & E-6 \\
\hline 7 & Amin Dyeing Mills Ltd. of Shastarpur. & $\begin{array}{l}\text { Discharge point of } \\
\text { industries }\end{array}$ & $\mathrm{E}-7$ \\
\hline 8 & $\begin{array}{c}\text { S.S Dyeing, Rana Enterprise etc. of Shampur } \\
\text { Industrial Zone. }\end{array}$ & $\begin{array}{l}\text { Connected drain of } \\
\text { industries }\end{array}$ & E-8 \\
\hline 9 & $\begin{array}{l}\text { Metro Textile and Dyeing Mills Ltd., Micro } \\
\text { Fiber Textile Mills Ltd. Brothers Dyeing Ltd., } \\
\text { Fatulla Post Office Road Industrial Zone }\end{array}$ & $\begin{array}{l}\text { Connected drain of } \\
\text { industries }\end{array}$ & E-9 \\
\hline
\end{tabular}

solid (TSS), total dissolved solid (TDS), dissolved oxygen (DO), hydrogen-ion-concentration $(\mathrm{pH})$, electrical conductivity (EC), turbidity, biochemical oxygen demand (BOD), chemical oxygen demand (COD) of the samples were measured using various standard methods (APHA,1976).

A quantitative analysis of fluoride $\left(\mathrm{F}^{-}\right)$, chloride $\left(\mathrm{Cl}^{-}\right)$, nitrite $\left(\mathrm{NO}_{2}^{-}\right)$, nitrate $\left(\mathrm{NO}_{3}^{-}\right)$ and sulfate $\left(\mathrm{SO}_{4}^{-}\right)$were determined by Ion chromatography (IC). A quantitative analysis of phosphorous was determined by UV spectrophotometer at $400 \mathrm{~nm}$ wave length. Phosphate $\left(\mathrm{PO}_{4}{ }^{3-}\right)$ concentration was determined from phosphorous (P) concentration using factor $(95 / 31=3.0645)$.

Further heavy metals such as lead $(\mathrm{Pb})$, zinc(Zn), cadmium (Cd) and cupper (Cu) concentrations were determined by using 
Table Ib. Locations and sources of the sampling sites of the surface water samples with ID numbers.

\begin{tabular}{|c|c|c|c|}
\hline SL. No. & Locations & Sources & Sample ID \\
\hline 10 & $\begin{array}{l}\text { D.N.D Channel in front of Sha Fateulla TextileMills } \\
\text { Ltd. of Fatulla Industrial Zone. }\end{array}$ & D.N.D Channel water & S.W-1 \\
\hline 11 & Fatulla Industrial zone & Lake water & S.W-2 \\
\hline 12 & D.N.D Channel of Jalkuri Bus Stand. & D.N.D Channel water & S.W-3 \\
\hline 13 & D.N.D Channel of Medical Road, Jalkuri. & D.N.D Channel water & S.W-4 \\
\hline 14 & D.N.D Channel in front of Sakil Dyeing, Jalkuri. & D.N.D Channel water & S.W-5 \\
\hline 15 & Near D.N.D Channel of Medical Road, Jalkuri. & Pond water & S.W-6 \\
\hline 16 & $\begin{array}{c}\text { Near D.N.D Main channel in front of Sakil } \\
\text { Dyeing , Jalkuri. }\end{array}$ & Lake water & S.W-7 \\
\hline 17 & $\begin{array}{c}\text { Near Rupashi Textile and Dyeing Mills Ltd. } \\
\text { of Shastarpur. }\end{array}$ & Pond water & S.W-8 \\
\hline 18 & $\begin{array}{l}\text { In front of Fatullah Dyeing and Calendaring } \\
\text { Mills Ltd. of Fatulla }\end{array}$ & Pond water & S.W-9 \\
\hline 19 & Mid Point of Jalkuri and Shibu Market & Lake water & S.W-10 \\
\hline 20 & $\begin{array}{l}\text { D.N.D Channel of Lamapara, Kutubpur, Fatullah, } \\
\text { Narayangonj. (Shibu Market-South Side) }\end{array}$ & D.N.D Channel water & S.W-11 \\
\hline 21 & Bhuigar Bus Stand & Lake water & S.W-12 \\
\hline
\end{tabular}

Anodic Stripping Voltammetry (AVS) technique.

\section{Data analysis}

The primary data were analyzed for descriptive statistics (Minimum Conc., Maximum Conc., Mean Conc. \& Std. Deviation ( \pm )) by using SPSS (Statistical Package for Social Sciences). Further the statistical correlation analysis such as Pearson Correlation coeffi- cient with (2 Tailed) Bivariate analysis of the data was done by SPSS.

\section{Results and Discussion}

Concentrations of the physicochemical properties of the effluents of textile dyeing industries

The concentration ranges of the physicochemical properties with the average value of the effluents of the study area are shown in Table II. The levels of pollution of the effluents were determined by comparing the 
Table II. Descriptive statistics of the physicochemical parameters of the effluent samples

\begin{tabular}{l|c|c|c|c}
\hline \multicolumn{1}{c|}{ Parameter } & Minimum & Maximum & Mean & Std. Devi. $( \pm)$ \\
\hline Temperature $\left({ }^{\circ} \mathrm{C}\right)$ & 30.00 & 80.20 & 50.22 & 16.68 \\
TSS $(\mathrm{mg} / \mathrm{L})$ & 736.00 & 1960.00 & 1123.11 & 389.22 \\
TDS $(\mathrm{mg} / \mathrm{L})$ & 391.00 & 46700.00 & 9123.78 & 14785.12 \\
Turbidity (FTU) & 60.10 & 316.90 & 130.37 & 83.74 \\
DO (mg/L) & .42 & 4.60 & 2.36 & 1.70 \\
pH & 7.59 & 11.91 & 9.88 & 1.38 \\
EC $(\mu \mathrm{s} / \mathrm{cm})$ & 795.00 & 60200.00 & 14109.56 & 19166.93 \\
BOD $(\mathrm{mg} / \mathrm{L})$ & 415.00 & 770.00 & 573.89 & 133.65 \\
COD $(\mathrm{mg} / \mathrm{L})$ & 860 & 1560.00 & 1223.33 & 305.53 \\
\hline
\end{tabular}

observed values of the various parameters with the inland surface water standard value recommended by DoE, Bangladesh (Huq, 2003) which is shown by the solid line in Fig. 2 and 3.

Highly colored liquid effluents with pungent odor were observed in the effluents of the studied industrial area. The average temperature of the effluent was found about $50^{\circ} \mathrm{C}$ which is slightly higher than DoE standard. The $\mathrm{pH}$ of the effluents was varied from 7.59 to 11.91 . The $\mathrm{pH}$ variation is primarily caused by different kinds of dye stuff used in the dyeing process in different industries. The average $\mathrm{pH}$ value was found 9.88 which is higher than the DoE standard. In textile dyeing industries $\mathrm{H}_{2} \mathrm{O}_{2}$ and $\mathrm{NaOH}$ are used as bleaching and kier agents. Higher $\mathrm{pH}$ approaches in effluents owing to the wastes composition of textile mills such as: $\mathrm{NaOCl}$, $\mathrm{NaOH}, \mathrm{Na}_{2} \mathrm{SiO}_{3}$, surfactants, sodium phos- phate. Water $\mathrm{pH}$ influences the other prope ties of water body, activity of organisms, and potency of toxic substances present in the aquatic environment. Excessive $\mathrm{pH}$ is harmful to aquatic life like fish and microorganism etc (Yusuff et al., 2005, Rose, 1979).

The electric conductivity (EC) is usually used for indicating the total concentration of the ionized constituents of water. The average values of electrical conductivity of the effluent is $14109.56 \mu \mathrm{s} / \mathrm{cm}$ which indicates that a large amount of ionic substances is released from textile industries like sodium, chloride etc. in the studied area. In Fig. 2 , line shows the standard value of EC recommended by DoE. The average concentrations of EC was found around 12 times higher than the DoE standard (Fig.2). Such a high value of EC is not suitable for aquatic life and irrigation purposes. The EC is an indirect measure of the ions or the charge carrying species in the 

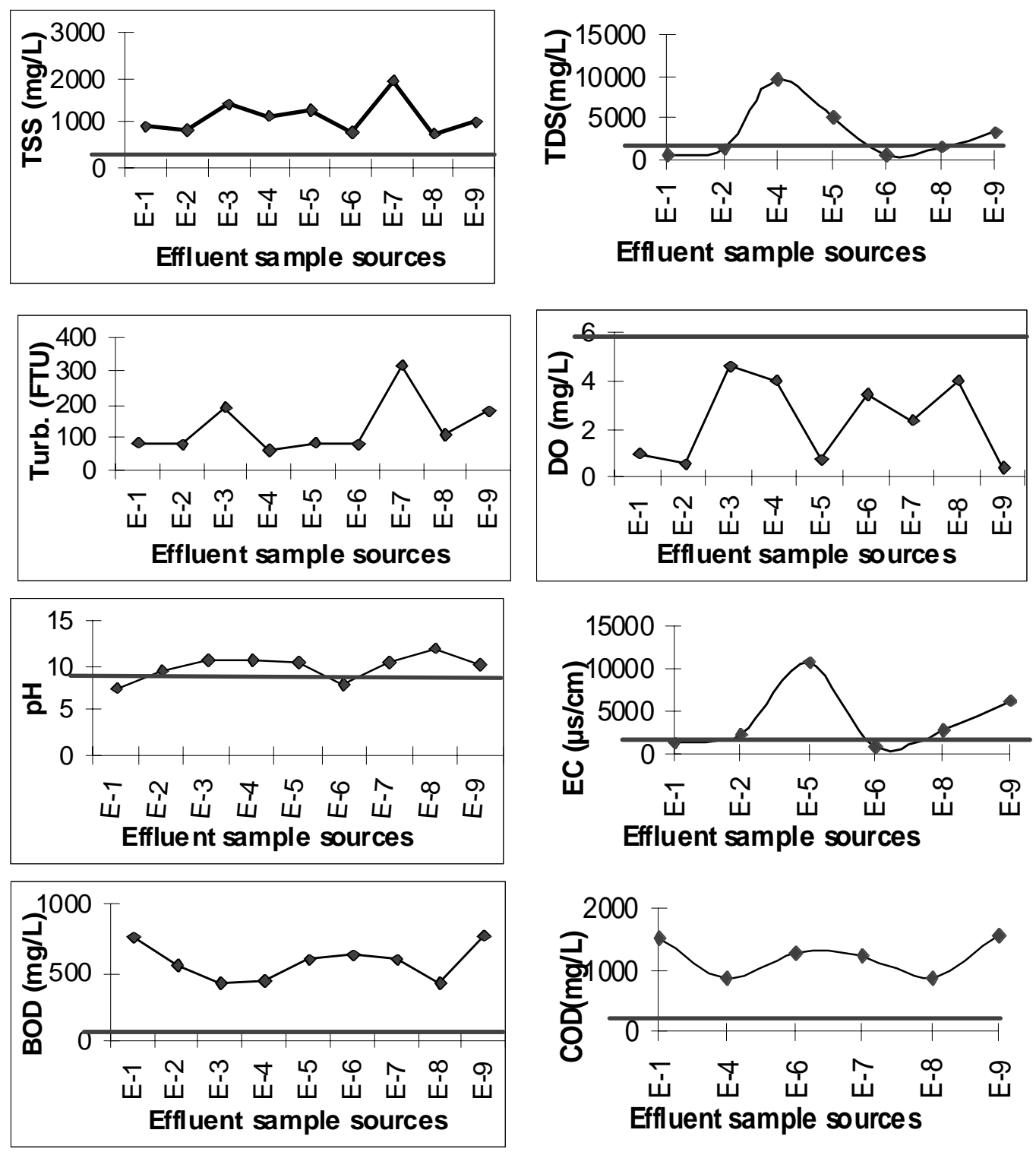

Fig. 2. The variation of the concentrations of the various physicochemical parameters with effluent sample sources. The solid line represents the standard value of the parameters recommended by DoE (Huq, 2003) 
effluents under the measurement conditions. It exhibited significant correlation with TSS, TDS, turbidity, $\mathrm{Cl}^{-}$and $\mathrm{PO}_{4}^{3^{-}}(0.96,0.99$, 0.86, 0.79 and 0.67).

Total suspended solids (TSS) denote the suspended impurities present in the water. Measurement of suspended particulate matter is important as they are responsible for pollutant transport in the aquatic environment. The TSS values of the effluents of the study area lie between 736 to $1960 \mathrm{mg} / \mathrm{L}$ and average value was found $1123 \mathrm{mg} / \mathrm{L}$ which exhibited significant correlation with TDS, EC, turbidity, Cl- and $\mathrm{PO}_{4}^{3^{-}}(0.97,0.96$, $0.82,0.72$ and 0.63 ). It is found that the effluent samples contain TSS concentration about 3 to 7 times higher than DoE standard (Fig. 2).

TDS in water mainly consist of ammonia, nitrite, nitrate, phosphate, alkalis, some acids, sulphates, metallic ions etc. The TDS values of the effluents of the study area lie between 391 to $46700 \mathrm{mg} / \mathrm{L}$ and average value was found $10283 \mathrm{mg} / \mathrm{L}$. It is found that most of theb effluent samples contain TDS concentration 3 to 7 times higher than DOE standard (Fig. 2). The high TDS value of effluent is not desirable because a high content of dissolved solids elevates the density of water, influences osmoregulation of fresh water organisms, reduces solubility of gases (like oxygen) and utility of water for drinking, irrigational and industrial purposes. It also exhibited significant correlation with
TSS, EC, turbidity, $\mathrm{Cl}^{-}$and $\mathrm{PO}_{4}^{3^{-}}$(0.93, 0.87, 0.99, 0.85 and 0.73).

Turbidity in water is caused by suspended and colloidal matter such as clay, silt, finely divided organic and inorganic matter, and plankton and other microscopic organisms. The turbidity of the effluents of the study area lie between 60 to 317 FTU and average value was found $130 \mathrm{FTU}$, which exhibited significant correlation with TSS, TDS EC and $\mathrm{Cl}^{-}$(0.82, 0.87, 0.86 and 0.89).

The DO of the effluents varied from 0.42 to $4.60 \mathrm{mg} / \mathrm{L}$ with average value $2.36 \mathrm{mg} / \mathrm{L}$. It is found that most of the effluents samples contain 2 to 19 times lower DO than DoE standard (Fig. 2). It exhibited significant correlation with $\operatorname{BOD}(-0.76)$. Oxygen is essential to all forms of aquatic life including those organisms responsible for the self purification processes in natural waters. Like terrestrial animals, fish and other aquatic organisms need oxygen to live. The presence of oxygen in water is a positive sign of a healthy body of water but the absence of oxygen is a signal of severe pollution.

Textile industries releases a lot of biochemical oxygen demanding wastes. The BOD values of the effluents varied from 415 to $770 \mathrm{mg} / \mathrm{L}$ and the average value was found $573.89 \mathrm{mg} / \mathrm{L}$ which exhibited significant correlation with DO and COD (-0.76 and 0.60). It is found that it contains 14 to 18 times higher BOD value than the DoE standard. BOD is an index of the biodegradable 
organics present. Biochemical oxygen demanding wastes consumes the dissolved oxygen from water. Excessive BOD is harmful to aquatic animals like fish and microorganisms. It also causes bad taste to the drinking water.

Chemical oxygen demand (COD) is defined as the amount of a specified oxidant that reacts with the sample under controlled conditions which is one of the most important parameter for assessing the quantity of chemically oxidizing matter in water. Textile industries release a lot of chemical oxygen demanding wastes. The COD values of the effluents varied from 860 to $1560 \mathrm{mg} / \mathrm{L}$ and the average value was found $815 \mathrm{mg} / \mathrm{L}$, which exhibited significant correlation with BOD ( 0.60). It is found that effluent samples contain COD value around 4 to 9 times higher than the DoE standard (Fig. 2).

\section{Concentrations of the anionic properties of the effluents of textile dyeing industries}

The concentration ranges of the anionic properties with the average value of the effluents of this area are shown in Table III.

The concentration of fluoride which is an important inorganic anion of the effluents varied from 0.02 to $1023 \mathrm{ppm}$. The average value of $\mathrm{F}^{-}$conc. of the effluents was found $162 \mathrm{ppm}$. It is found that effluent samples contain $\mathrm{F}^{-}$conc. around 16 times higher than the DoE standard (Fig.3). It exhibited significant correlation with $\mathrm{NO}_{2}{ }^{-}(0.70)$.

The $\mathrm{Cl}^{-}$conc. of the effluents varied from 1035 to 69494 ppm and the average value was found 12714 ppm. It exhibited significant correlation with TSS, TDS, EC, turbidity and $\mathrm{PO}_{4}^{3-}(0.72,0.84,0.89,0.79$ and 0.69). It is found that the samples contain excess $\mathrm{Cl}^{-}$ion around 3 times higher than the DoE standard (Fig. 3). The different types of textile and dyeing effluents contain bleach liquor which is quite toxic due to the presence of chloride ion and a minor quantity may prove lethal to fish.

Nitrite is one of the critical nutrients for the growth of algae and helps accelerating the eutrophication. Industrial waste, domestic

Table III. Descriptive statistics of the anionic parameters of the effluent samples

\begin{tabular}{|c|c|c|c|c|}
\hline Anion concentration & Minimum & Maximum & Mean & Std. Devi. $( \pm)$ \\
\hline $\mathrm{F}^{-} \quad(\mathrm{ppm})$ & $* \mathrm{BDL}$ & 1013.00 & 162.39 & 332.56 \\
\hline $\mathrm{Cl}^{-} \quad(\mathrm{ppm})$ & 1035.00 & 69494.00 & 12714.18 & 23529.63 \\
\hline $\mathrm{NO}_{2}^{-}$(ppm) & $* \mathrm{BDL}$ & 14.00 & 3.54 & 5.49 \\
\hline $\mathrm{NO}_{3}^{-}(\mathrm{ppm})$ & $* \mathrm{BDL}$ & 850.00 & 108.87 & 278.90 \\
\hline $\mathrm{SO}_{4}^{2-}(\mathrm{ppm})$ & $* \mathrm{BDL}$ & 90502.00 & 14964.26 & 31086.81 \\
\hline $\mathrm{PO}_{4}{ }^{3^{-}}(\mathrm{ppm})$ & 191.30 & 5969.03 & 1737.89 & 1928.00 \\
\hline
\end{tabular}

*BDL- Below Detection Limit 
wastes are the important sources of it. The determination of nitrate in drinking water is of prime importance because of the disease methamoglobonemia caused by its excessive presence. The $\mathrm{NO}_{2}^{-}$concentration of the effluent varied from 0.07 to $14 \mathrm{ppm}$. Average value was found $3.5 \mathrm{ppm}$ and significantly correlated with $\mathrm{F}^{-}$and $\mathrm{SO}_{4}{ }^{2-}(0.70$ and 0.93$)$. In effluents, $\mathrm{NO}_{3}{ }^{-}$conc. varied from 0.06 to $850 \mathrm{ppm}$ and the average value was found
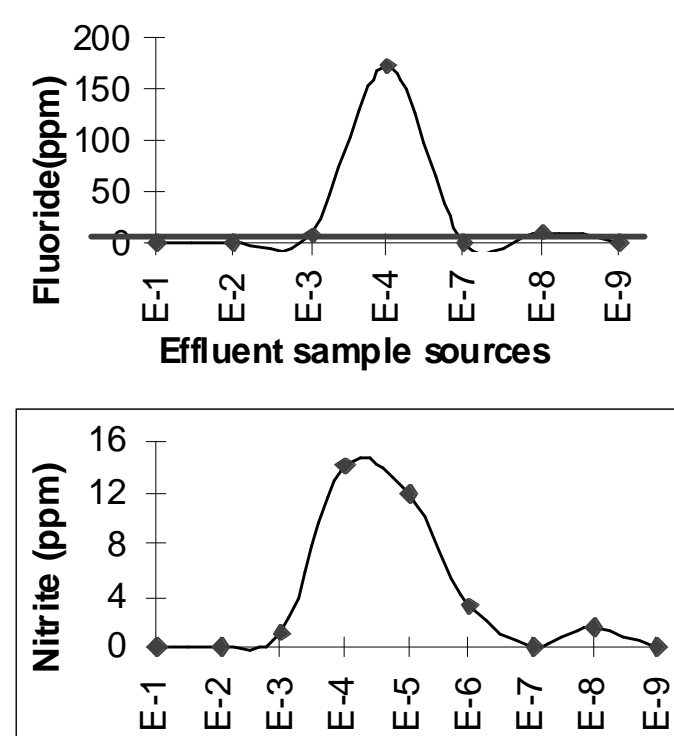
Effluent sample sources

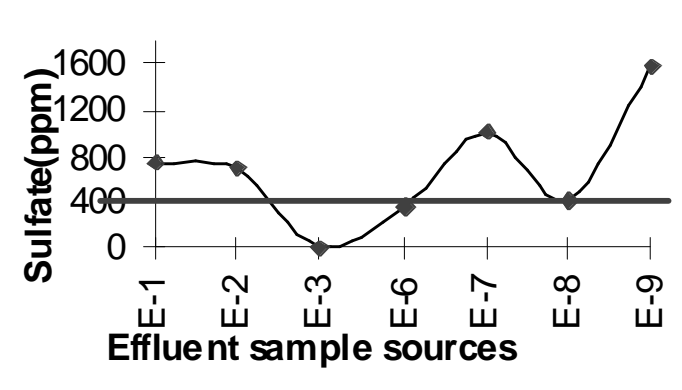

Fig. 3. The variation of the concentration of the various anionic parameters with effluent sam-
ple sources. The solid line represents the standard value of the parameters recom-

Fig. 3. The variation of the concentration of the various anionic parameters with effluent sam-
ple sources. The solid line represents the standard value of the parameters recommended by DoE

108.87 ppm. In Fig. 3, solid line shows the standard value of $\mathrm{NO}_{3}^{-}$for drinking water purpose which was recommended by DoE. It is found that the average value is around 10 times higher than the DoE standard (Fig. 3).

Sulfate is an important anion imparting hardness to the water. It may undergo transformations to sulphur or hydrogen sulphide depending largely upon the redox potential
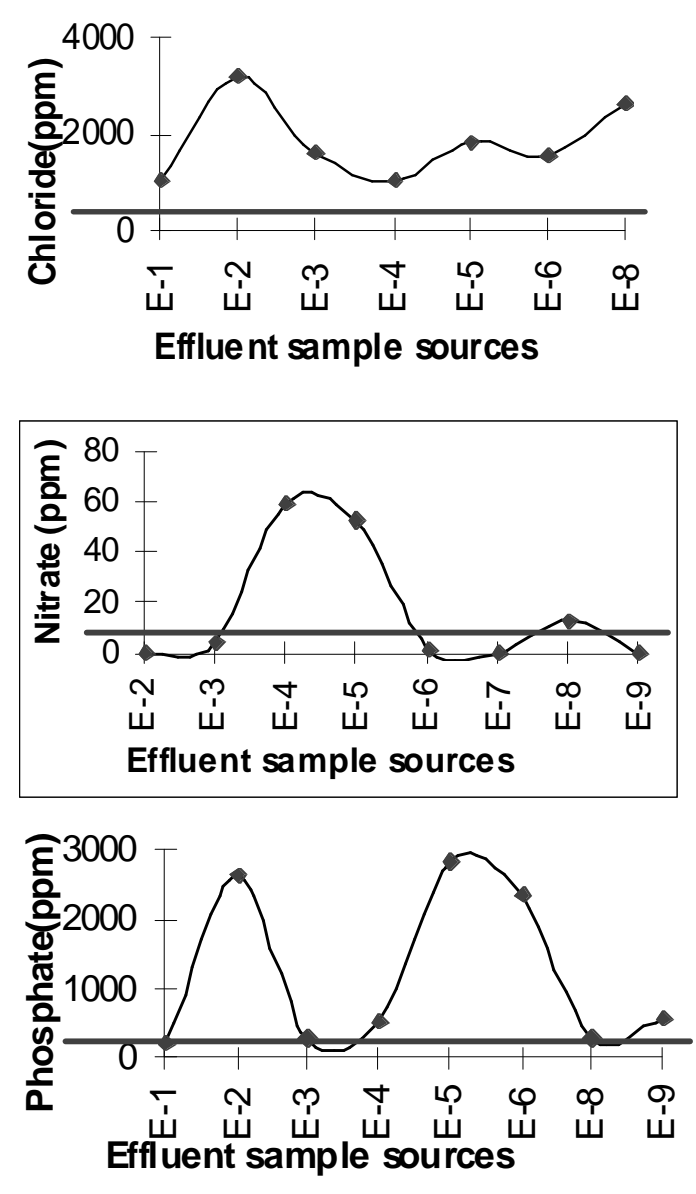
of the water. In the effluents, $\mathrm{SO}_{4}{ }^{2-}$ conc. varied from 0.27 to $90502 \mathrm{ppm}$ and average value was found $14964 \mathrm{ppm}$. It exhibited significant correlation with $\mathrm{NO}_{2}^{-}$(0.92). It is found that the average value is around 37 times higher than the DoE standard for drinking purposes (Fig. 3).

Phosphorus (Phosphate-phosphorus) is generally the limiting nutrient for algal growth and controls the primary productivity of water body. High levels of phosphate may originate from municipal wastewater discharges, since it is an important component of detergents. Therefore, the measurement of phosphate is assumed considerable importance. In the effluents $\mathrm{PO}_{4}{ }^{3-}$ conc. varied from 191.30 to $5969.03 \mathrm{ppm}$ and the average value was found $1737.89 \mathrm{ppm}$. It is found that the average concentration is 50 times higher than DoE standard (Fig. 3). It exhibited significant correlation with TSS, TDS, EC and $\mathrm{Cl}^{-}$(0.62, 0.73, 0.67 and 0.70).
Concentrations of the heavy metals in the effluents of textile dyeing industries

The average concentrations of the of the heavy metals such as $\mathrm{Pb}, \mathrm{Cd}, \mathrm{Zn}$ and $\mathrm{Cu}$ of the effluents of the study area were found $0.0001 \mathrm{ppm}, 0.001 \mathrm{ppm}, 0.0001 \mathrm{ppm}$ and $0.001 \mathrm{ppm}$ respectively which are within the permissible limit recommended by DoE. It suggested that the textile dyeing industries of the study area uses organic dyes instead of heavy metal pigment dyes.

\section{Concentrations of the physicochemical prop-} erties of the surface water

Further the impacts of the pollutants of the effluents on the surface water were studied by measuring the various parameters of the surface water collected from the surrounding ponds, lakes and DND main channel of the studied industrial area. The levels of pollution of the surface water were determined by

Table IV. Descriptive statistics of the physicochemical parameters of surface water

\begin{tabular}{|c|c|c|c|c|}
\hline Parameter & Minimum & Maximum & Mean & Std. Devi. $( \pm)$ \\
\hline Temperature ( $\left.{ }^{\circ} \mathrm{C}\right)$ & 32.00 & 38.00 & 33.75 & 1.71 \\
\hline TSS (mg/L) & 344.00 & 1132.00 & 597.33 & 225.79 \\
\hline TDS (mg/L) & 372.00 & 2610.00 & 1369.33 & 780.00 \\
\hline Turbidity (FTU) & 19.30 & 176.55 & 47.87 & 43.68 \\
\hline DO (mg/L) & 0.00 & 2.57 & 0.84 & 0.75 \\
\hline $\mathrm{pH}$ & 7.75 & 10.15 & 8.70 & 0.72 \\
\hline $\mathrm{EC}(\mu \mathrm{s} / \mathrm{cm})$ & 803.00 & 3220.00 & 2076.58 & 892.55 \\
\hline BOD (mg/L) & 150.00 & 977.00 & 584.75 & 249.66 \\
\hline COD (mg/L) & 400 & 2004.00 & 1264.67 & 534.86 \\
\hline
\end{tabular}


comparing the observed values of the various parameters with the inland surface water standard and drinking water standard value recommended by DoE, Bangladesh (Haq, 2003). The concentration ranges of the physicochemical parameters of the surface water with the average values are shown in Table IV.

Slightly colored surface water with pungent odor was observed in surface water of the studied industrial area. The $\mathrm{pH}$ of the surface water was varied from 7.75 to 10.15 and the average value was found 8.70 . It exhibited significant correlation with TDS and turbidity (0.66 and 0.68). The EC value of the surface water of the study area was varied from 803.00 to $3220.00 \mathrm{mg} / \mathrm{L}$ and the average value was found $2076.58 \mathrm{mg} / \mathrm{L}$. The average EC value of the surface water samples was found 2 times higher than DoE standard. It exhibited significant correlation with TDS and $\mathrm{pH}$ ( 0.98 and 0.61).

The TSS value of the surface water of the study area was varied from 344 to 1132 $\mathrm{mg} / \mathrm{L}$ and the average value was found $597.33 \mathrm{mg} / \mathrm{L}$. The average TSS value of the surface water samples was found 4 times higher than DoE standard. It exhibited significant correlation with turbidity, BOD and $\mathrm{NO}_{2}^{-}$( $0.72,0.59$ and 0.64$)$. The TDS values of the surface water of the study area lie between 372 to $2610 \mathrm{mg} / \mathrm{L}$ and average value was found $1369.33 \mathrm{mg} / \mathrm{L}$. It exhibited significant correlation with $\mathrm{pH}$ and EC (0.66 and 0.98 ). The turbidity of the surface water of the study area lie between 19 to 176 FTU and average value was found 45 FTU. It exhibited significant correlation with TSS and $\mathrm{pH}(0.72$ and 0.68$)$.

The DO of the surface water varied from 0.42 to $2.57 \mathrm{mg} / \mathrm{L}$ with average value 1.36 $\mathrm{mg} / \mathrm{L}$. It is found that all the surface water samples contain DO value below the DoE standard when they discharge into surface water and irrigation land. The BOD values of the surface water varied from 150 to 977 $\mathrm{mg} / \mathrm{L}$ and the average value was found $584.75 \mathrm{mg} / \mathrm{L}$. The average BOD value of the surface water was found 6 times higher than the DoE standard. It exhibited significant correlation with TSS (0.59). The COD values of the surface water varied from 400 to $2004 \mathrm{mg} / \mathrm{L}$ and the average value was found $1264.67 \mathrm{mg} / \mathrm{L}$. The average COD value of the surface water was found 3 times higher than the DoE standard.

\section{Concentrations of the anionic properties of the surface water}

Further the concentration of the anionic parameters of the surface water of the surrounding lakes, ponds and D.N.D main channel of the studied textile dyeing industries was also studied in order to know the impact of the effluents on the surface water quality.

The concentration ranges of the anionic parameters of the surface water with the 
average values are shown in Table V. Fluoride is an important inorganic anion of water. The $\mathrm{F}^{-}$concentration of the surface water of the studied industrial area varied from 0.02 to $7.6 \mathrm{mg} / \mathrm{L}$ and the average value was found $3.33 \mathrm{mg} / \mathrm{L}$. The average $\mathrm{F}^{-}$concentration of the surface water contains 3 times higher value than DoE standard. The chloride concentration of the water samples varied from 1247 to $6756.70 \mathrm{ppm}$ and the average value was found $3699.83 \mathrm{ppm}$. The average values of the samples were found 6 times higher than DoE standard for irrigation and drinking purpose. concentrations of the surface water varied from 263.8 to $7381 \mathrm{ppm}$ and the average value was found $1443.87 \mathrm{ppm}$. The average value was found 3 times higher than DoE standard. The $\mathrm{PO}_{4}{ }^{3-}$ concentration of the surface water varied from 93.80 to $352.14 \mathrm{ppm}$. The average value of $\mathrm{PO}_{4}{ }^{3-}$ in the collected surface water samples was found 292.89 ppm which is 8 times higher than the DoE standard. Excess $\mathrm{PO}_{4}{ }^{3-}$ in the collected surface water indicates the presence of pollution and is largely responsible for eutrophication.

Table V. Descriptive statistics of the anionic parameters of the surface water samples

\begin{tabular}{l|c|c|c|c}
\hline Anion concentration, ppm & Minimum & Maximum & Mean & Std. Devi. $( \pm)$ \\
\hline $\mathrm{F}^{-}$ & *BDL & 7.60 & 3.33 & 3.53 \\
$\mathrm{Cl}^{-}$ & 1247.10 & 6756.70 & 3699.83 & 2136.28 \\
$\mathrm{NO}_{2}{ }^{-}$ & $*$ BDL & 312.00 & 49.49 & 97.99 \\
$\mathrm{NO}_{3}{ }^{-}$ & $*$ BDL & 227.10 & 55.80 & 66.81 \\
$\mathrm{SO}_{4}{ }^{2-}$ & 263.80 & 7381.10 & 1443.87 & 1962.82 \\
$\mathrm{PO}_{4}{ }^{3-}$ & 93.80 & 352.14 & 292.89 & 66.68 \\
\hline
\end{tabular}

The $\mathrm{NO}_{3}{ }^{-}$concentrations of the surface water of the studied industrial area varied from 0.02 to $227.1 \mathrm{mg} / \mathrm{L}$ and the average value was found $55.8 \mathrm{mg} / \mathrm{L}$.The average of the surface water was around 5 times higher than the DoE standard for drinking purpose. The $\mathrm{NO}^{2-}$ concentrations of the surface water of the studied industrial area was varied from 0.07 to $312.00 \mathrm{mg} / \mathrm{L}$ and the average value was found $49.49 \mathrm{mg} / \mathrm{L}$. The $\mathrm{SO}_{4}{ }^{2-}$

\section{Conclusions}

The concentrations of the various physicochemical, anionic parameters and heavy metals of the effluents and surface water inside D.N.D embankment, Narayanganj were studied in order to assess the impact of various pollutants of textile dyeing effluents on the surface water quality of this area by industrial activities. The results of the study reveal that textile dyeing industries inside 
D.N.D Embankment, Narayanganj area discharges large quantities of effluent composed of various physicochemical and anionic pollutants at significant higher level than standard value of DoE. However, the heavy metal concentrations of the effluents are found within the limit of DoE standard. Therefore, the level of pollution of the effluents due to textile dyeing industries of D.N.D. embankment area is quite alarming. The surface water of the D.N.D main channel, ponds and lakes around the studied textile dyeing industries also contain various physicochemical and anionic pollutants at intolerable limit. Further there is a significant correlation among some important water parameters of the effluents and surface water. Correlation analyses indicate that the accumulation pattern of physicochemical and anionic parameters of the effluents and surface water of the study area are correlated with one another to a significant extent. The above findings suggested that the surface water of D.N.D. embankment area is highly polluted by the industrial effluents of the study area.

\section{References}

APHA. (1976). Standard methods for the examination of water and waste water (14th ed) American Public Health Association. Washington 1193.

Chindah, A.C. Braide, A.S. Sibeudu, O.C. (2004). Distribution of hydrocarbons and heavy metals in sediment and a crustacean (shrimps-Penaeus notialis) from the bonny
/ newcalabar river estuary, 9: 1-14.

Ghoreishi, S.M. Haghighi, R. (2003). Chemical Catalytic Reaction and Biological Oxidation for Treatment of nonBiodegradable Textile Effluent, Chemical Engineering Journal, 95: 163-169.

Haque, S. Yasmin, H. Rahman, M.H. (2002). Environmental Pollution in Bangladesh, Earth Community Organization (ECO).

Huq, M.E. (2003) A Compilation of Environmental Laws of Bangladesh, Administrated by the Department of Environment (DOE).

Nemerow, N.L. (1978). Industrial Water Pollution: Origins, Characteristics and Treatment. Addison Wesley, Reading, Massachusetts, 738.

Park, C.C. (1980). Ecology and Environment Management, Dawson, West View Presses Colorado.

Rahman, S. Bakri, Al. D. (2002). Impact of Wastewater Effluent on the Urban Waterways on Upland Catchments. (BAPA), 1: 926-939.

Rouse, R.D. (1979) Water quality management in pond fish culture. In: Research and Development Series No. 22, Project: AID/DSAN-G 0039, Auburn University, Alabama, USA.

Yusuff, R.O. Sonibare, J.A. (2005). Character-ization of textile industries' effluents in Kaduna, Nigeria and pollution implications. Global Nest: the Int. J. 6 (3): 212-221.

Received : January, 142008

Accepted : June, 10, 2008. 
